\title{
GEOSCIENCE DEBATE
}

\section{The Rationale and Essential Elements for the New 'Pirate' Model of Caribbean Tectonics}

\author{
Fraser Keppie \\ Nova Scotia Department of Natural \\ Resources \\ 1701 Hollis Street \\ Halifax, NS, Canada, B3J 2T9 \\ E-mail: keppiedf@gov.ns.ca
}

\section{IN BRIEF}

Different studies have proposed either Pacific or in situ models for the tectonic evolution of the Caribbean Plate. Pacific model proponents, in general, extrapolate data obtained at the northern, eastern, and southern boundaries of the Caribbean Plate to indicate the arrival of the Caribbean Plate from the west relative to North and South America since the Late Cretaceous. In contrast, for the same period of time, in situ model proponents interpret other data as evidence of west - east extension of the western or central Caribbean and the possible preservation of Atlantic or proto-Caribbean lithosphere within present Caribbean Plate boundaries. The limitations of both models in explaining some parts of the geological record provide the rationale for considering further alternatives. The 'Pirate' model of Caribbean tectonics is a new hypothesis for the Cenozoic era that involves: (1) microplate capture in the western Caribbean of blocks derived from adjacent parts of North and South America, and (2) counter-clockwise rotation of the Caribbean Plate relative to North and South America. Whereas new Caribbean lithosphere is hypothesized to have entered Middle America from the west in the Pacific model, and from depth in the in situ model, the Pirate model postulates that new Caribbean lithosphere entered the western Caribbean region from the north or south.

\section{INTRODUCTION}

Current tectonic models for the Caribbean Plate suggest that it either derived entirely from the Pacific realm (i.e. Pacific models; Wilson 1966; Pindell and Dewey 1982; Pindell and Kennan 2009), or else that it evolved principally within its present position (i.e. in situ models; Phipps Morgan et al. 2008; James 2009a, b). In North and South American reference frames, eastward displacement of the Caribbean Plate relative to North and South America creates implicit gaps in the west (or central) parts of the Caribbean region that must be filled. In Pacific models, new lithosphere is hypothesized to have entered the western Caribbean region from the west; in in situ models, new lithosphere is hypothesized to have formed and to have entered the western (or central) Caribbean region from depth. A new model - the 'Pirate' model - is herein proposed, whereby the lithosphere presently occupying the western Caribbean Plate is interpreted to derive from the north or south (Keppie 2012). For example, the Chortis Block and lithosphere now forming the northwestern part of the Caribbean Plate are interpreted to have been captured from the western Gulf of Mexi- co region during the late Cretaceous and Cenozoic. The northern Andes, Maracaibo, and Bonaire blocks now overlying the southern part of the Caribbean Plate are interpreted to have been partially captured from northwestern South America (Keppie 2012).

The three models or classes of model for Caribbean tectonics incorporate many differences in the interpretation of the geological record, but the fundamental distinction relates to the hypothesized origin of lithosphere now occupying the western Caribbean region. In principle, none of the three models is mutually exclusive and a combination of all three could have taken place. However, arguments in favour of the dominance of any of the models must explain how American Caribbean displacements were accommodated by terminal triple junctions or corner zones in the western (or central) Caribbean (Guzman-Speziale 2010; Authemayou et al. 2011; Keppie 2012). The purpose of this paper is to explain the basic differences in the interpreted evolution of the western Caribbean triple junction or corner zones between Pacific, in situ, and Pirate model proponents and how the different interpretations lead to the different end-member models of Caribbean tectonics. Longer papers published elsewhere can be consulted for readers interested in more detailed reconstructions implementing each of the Pacific, in situ, and Pirate model hypotheses (James 2009a; Pindell and Kennan 2009; Keppie 2012). 


\section{A Free-air gravity anomaly (Sandwell v18.1)}

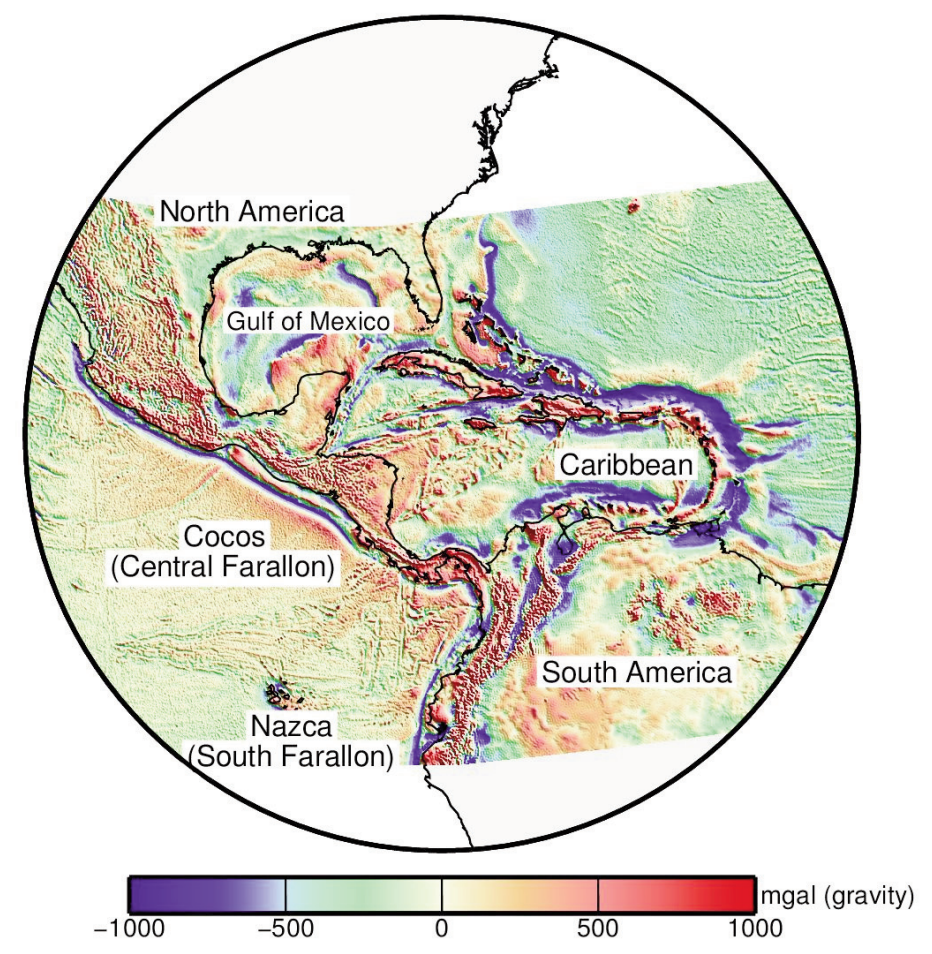

\section{B Tectonic features discussed in text}

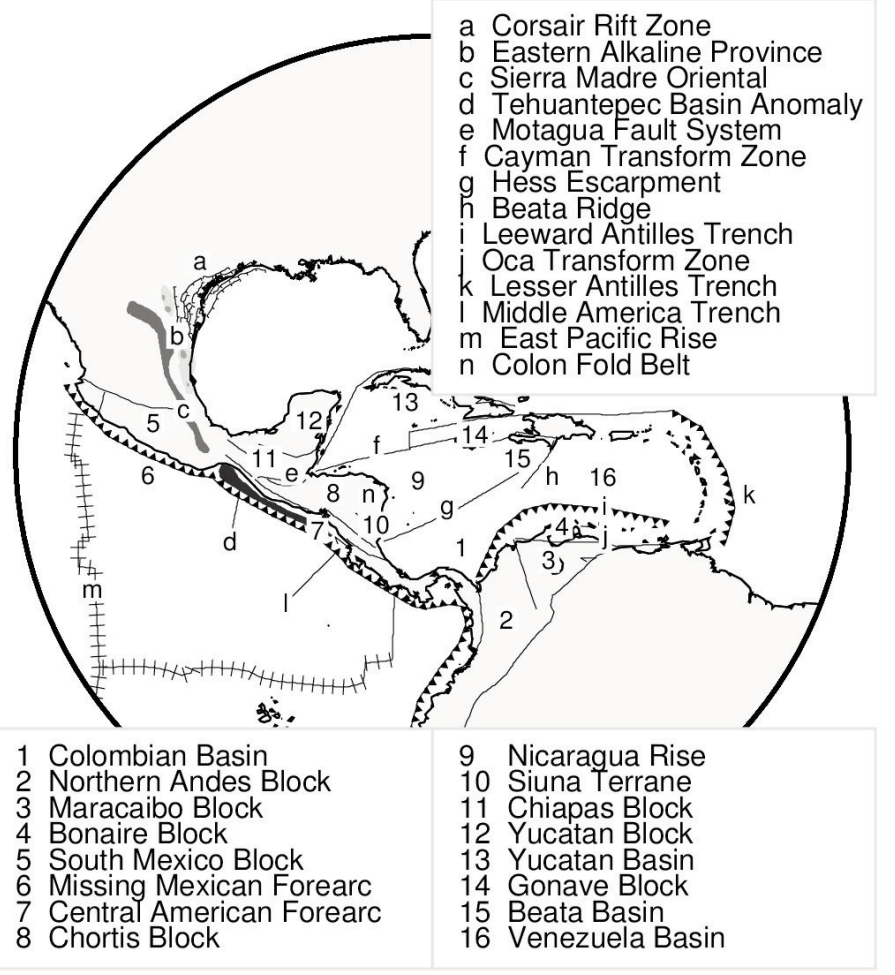

Figure 1. (A) Free-air gravity anomaly from Sandwell and Smith (2009) for the Caribbean region. (B) Interpreted tectonic features for the Caribbean region.

\section{THE PACIFIC MODEL OF CARIBBEAN TECTONICS}

The standard Pacific model (Pindell et al. 2006) is able to explain many aspects of Caribbean geology and tectonics and will not be reiterated here. This paper addresses only the potential problems the standard Pacific model encounters in relation to the Late Cretaceous and Cenozoic evolution of the western Caribbean Plate corners and the Middle American Trench at the western Caribbean Plate boundary (Fig. 1). Since the Pacific model has evolved over the past half century, this evaluation is based primarily on the recent update presented by Pindell and Kennan (2009).

The geological record indicates considerable complexity in the evolution of the westernmost part of the Caribbean region, including: (1) curvature of northern Caribbean Plate boundary shear zones to the northwest (Guzmán-Speziale 2009, 2010), and curvature of southern Caribbean Plate boundary shear zones to the southwest (Audemard 2009), prior to reaching the Middle American Trench (Figs. 1, 2); (2) evidence for microplate capture and/or pull-up tectonics across the western Caribbean corners in the last ca. 10 my (Andreani et al. 2008; Audemard 2009; Authemayou et al. 2011); and (3) detachment of the Central American forearc from the main part of the Caribbean Plate (Funk et al. 2009). Presently, most studies have suggested that these complexities are geologically young (e.g. <10 Ma); whatever their age, they obscure the more ancient history of western Caribbean tectonics.

Uncertainty over how the northern and southern Caribbean Plate boundaries may have terminated at the Middle American Trench between the Late Cretaceous and the Late Miocene (i.e. 80 to10 Ma) permit two major variants of the Pacific model (Fig. 2). The now standard variant invokes stable trench-trench-trench (T-T-T) triple junctions at the western Caribbean Plate corners (Pindell and Kennan 2009), whereas alternative models invoke stable fault-fault-trench (F-F-T) triple junctions along the western parts of either or both of the northern and southern Caribbean Plate boundaries (Pindell and Dewey 1982; Keppie and
Morán-Zenteno 2005). The T-T-T variant implies that Farallon subduction under western North and South America is faster than Farallon subduction under the western Caribbean. Consequently, given margins for southwest North America and northwest South America that are oblique to the relative motion of the Caribbean Plate, T-T-T triple junctions could have migrated southeast or northwest, respectively, along these margins at the trailing corners of the Caribbean Plate (Fig. 2A). On the other hand, the F-F-T variant implies that the termination of the northern and southern Caribbean Plate boundaries occurs simply due to shortening at the Middle American Trench (because, moving east to west, the northern boundary shear sense would switch from sinistral to dextral at the northern F-F-T triple junction, and the southern boundary shear sense would switch from dextral to sinistral at the southern F-F-T triple junction; Fig. 2B). What is essential to appreciate in both models is that deformation is implied and required in the subducting plate (or plates), i.e. the Farallon Plate prior to ca. 23-25 Ma, and subsequent- 


\section{A Pacific Model - TTT Variant}

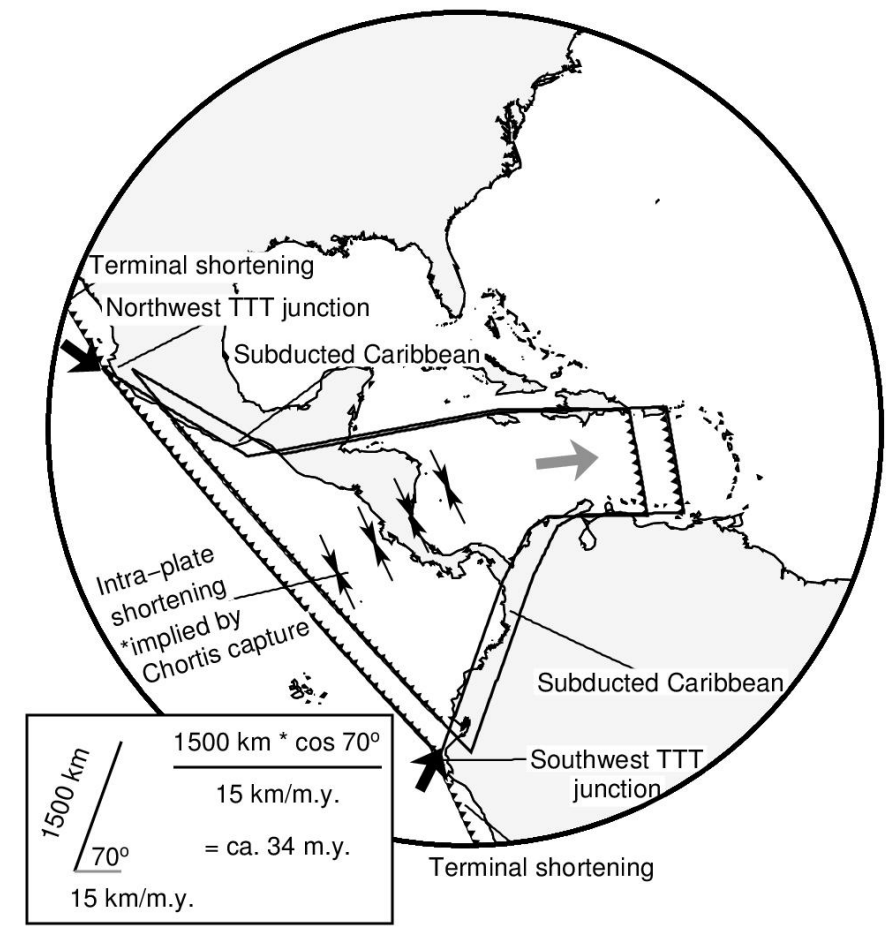

B Pacific Model - FFT Variant

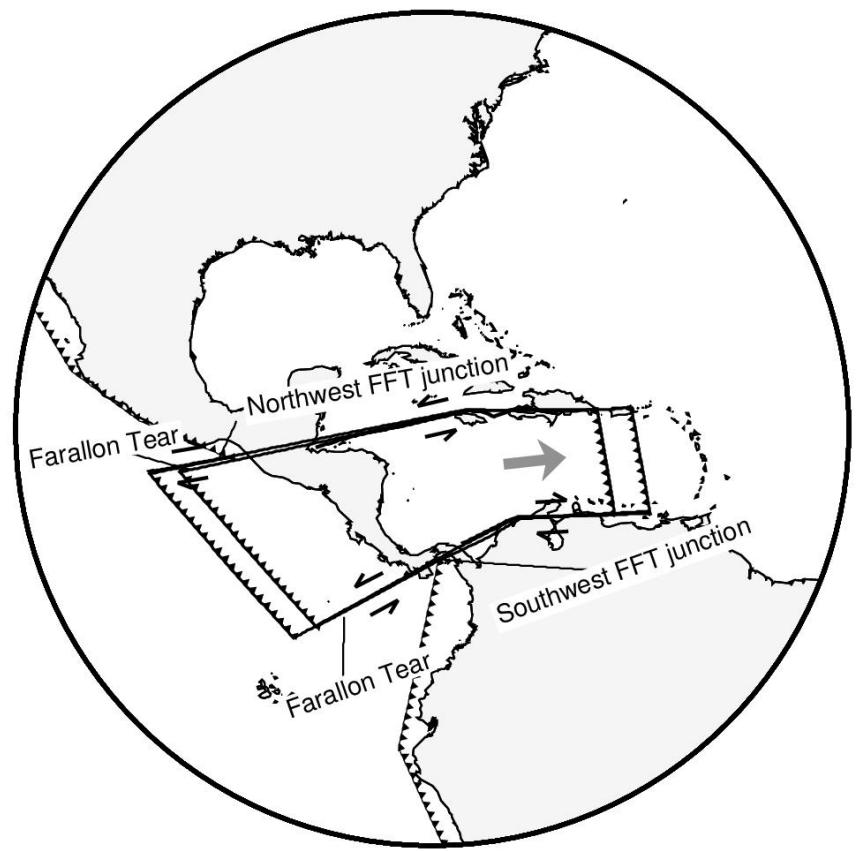

Figure 2. (A) Pacific model with trench-trench-trench triple junctions at western Caribbean Plate corners (after Pindell and Kennan 2009). (B) Pacific model with fracture-fracture-trench triple junctions at the northern and southern Caribbean Plate boundaries (after Keppie and Morán-Zenteno 2005).

ly its Cocos and Nazca daughter plates (Lonsdale 2005). A transient bend in the Farallon slab must migrate eastward under the American margins in tandem with the migrating T-T-T triple junctions inferred at the western Caribbean Plate corners. Or, transform faults must propagate into the Farallon slab under the western Caribbean Plate in order to accommodate the inferred F-F-T triple junctions inferred along the northern and southern Caribbean Plate boundaries (Fig. 2).

A number of geological inconsistencies arise from the T-T-T variant in terms of the geological record at the surface of Earth (e.g. James 2009b; Keppie 2012). First, a fundamental requirement of the Pacific model in the northwest Caribbean is the identification of a connection between the northern Caribbean Plate boundary and the Middle American Trench across the Tehuantepec Basin (Fig. 1B); this identification has so far proved elusive (e.g. Ortega-Gutiérrez et al. 2007; DeMets et al. 2010; Authemayou et al. 2011). Furthermore, the Tehuantepec Basin appears to be underlain by an undisturbed sequence of Late Cretaceous to present sedimentary rocks that crosses the projected trace of any connecting fault (Keppie et al. 2009; Morán-Zenteno et al. 2009) and an intact gravity anomaly (Fig. 1B).

Second, a key feature of the T-T-T variant is the detachment and capture of the Chortis Block by the Caribbean Plate as the latter moved past the southwestern margin of Mexico (Pindell and Dewey 1982). In this scenario, the Chortis Block is hypothesized to represent the forearc block inferred to have been removed from southern Mexico during the Cenozoic (e.g. Keppie et al. 2012); ca. 50-75 my are required to achieve the removal of the Chortis Block from the southwestern Mexican margin, and shortening is required between the Chortis Block and the main part of the Caribbean Plate in order for the Chortis Block to entrain with the modern Caribbean Plate (Pindell and Kennan 2009; Fig. 2A). To implement this model, further triple junctions are actually implied at the corners of the Chortis Block dur- ing its proposed transfer: the northwest Chortis Block corner is inferred to have been a trench-trench-fault ( $\mathrm{T}$ T-F) triple junction, the southwest Chortis Block corner is inferred to have been a trench-trench-trench (T-TT) triple junction, and the northeast Chortis Block corner is inferred to have been a rift-fault-trench (R-F-T) triple junction. In contrast with this model, however, removal of the southern Mexico forearc appears to have taken place over ca. 6 my during the Late Oligocene/Early Miocene and thus may record a case of rapid subduction erosion (Keppie et al. 2009; Keppie et al. 2012). Nonetheless, development of the Colon foldbelt in eastern Nicaragua, and possible ophiolite obduction at the southern margin of the Siuna terrane may record evidence of Cenozoic shortening between the Chortis Block and the Caribbean Plateau to the south (Rogers et al. 2007; Pindell and Kennan 2009). However, these events and their possible relation to the inferred ChortisCaribbean convergence has not been assessed in depth (e.g. Rogers et al. 
2007). Finally, a number of geological correlations can be drawn between the Mesozoic geology of the Yucatan and Chortis blocks, which might be considered unlikely if the Chortis Block originated off southwestern Mexico (James 2009a, b; Keppie and Keppie 2012).

Third, the present interpretation of the T-T-T triple junction at the southwest Caribbean Plate corner may be logically inconsistent. Pindell and Kennan (2009) invoked a stable T-T-T triple junction at the southwest Caribbean Plate corner for ca. 80 my or more. Yet, if the coastline traversed by this triple junction was ca. $1500 \mathrm{~km}$ in length and lay at ca. $70^{\circ}$ to a ca. 15 $\mathrm{km} / \mathrm{my}$ average Caribbean - South America relative motion vector, then it can only have been stable for ca. 34 $\mathrm{Ma}$ at the most (Fig. 2A, bottom left corner). Given conservative estimates for the geometry of the southwest Caribbean Plate corner, the purported termination of the southern Caribbean Plate boundary by a northeastward migrating T-T-T triple junction is impossible for ca. 46 my (80 my - 34 my). This discrepancy increases markedly if the traversed coastline were shorter, the angle to the Caribbean - South America relative motion vector were greater, or the magnitude of the Caribbean - South America relative motion was greater, all of which may have been the case. This conflict between proposed block motions for the Caribbean plateau (e.g. Ross and Scotese 1988) and for the Middle America Trench (e.g. Pindell and Kennan 2009; Gurnis et al. 2012) is starkly illustrated in the global synthesis of Seton et al. (2012), in which the Caribbean plateau is seen to cross or jump the Middle America Trench during its purported eastward migration during the Cenozoic.

The standard T-T-T Pacific model is also curious from a geodynamic perspective. Most geodynamic studies indicate that slab-pull forces dominate the evolution of subduction zones and, in particular, the absolute rollback of trenches (e.g. Lallemand et al. 2005; Schellart et al. 2007; Stegman et al. 2010). In the Caribbean case, the physics would predict similar rollback of the Farallon slab west of North, Central, and South America. In contrast, the Pacific model implies that rollback of the Farallon slab was faster west of North and South America than west of Central America (Fig. 2A). The rationale for hypothesizing faster rollback is the observation of strike-slip shear between the North and South American plates and the Caribbean Plate. However, strike-slip shear across the northern and southern Caribbean Plate boundaries implicate changes to upper plate forces at the Middle American Trench only. Consequently, the Pacific model implies that upper plate forces drove the proposed different rates of Middle American Trench rollback through time. This seems unlikely because it contradicts the conclusions of most mechanical studies as just noted.

\section{THE IN SITU MODEL OF CARIBBEAN TECTONICS}

Proponents of the in situ model of Caribbean tectonics have hypothesized that the western corners of the Caribbean Plate have been mostly fixed to North and South American Plate reference frames since the Late Cretaceous (Phipps Morgan et al. 2008; James 2009a). This hypothesis could solve all of the concerns with the Pacific model just discussed, and leads in turn to the suggestion that Atlantic or proto-Caribbean lithosphere may be preserved within the modern Caribbean Plate (cf. James 2009a). In situ model proponents achieve fixed western Caribbean Plate corners in North and South American reference frames by interpreting smaller displacements between the American and Caribbean Plate than generally inferred (e.g. James 2009a; Fig. 3A), or that the Caribbean region has widened across a zone of rifting in its western or central regions (Phipps Morgan et al. 2008, James 2009a; Fig. 3B). However, this interpretation is in conflict with evidence for large relative displacements at the northern, eastern, and southern Caribbean Plate boundaries, and the lack of evidence for equivalent intraplate rifting within the western or central Caribbean region (e.g. Pindell et al. 2006).

In general, minimum estimates of relative displacement at the northern, eastern, and southern Caribbean Plate boundaries are based on: (1) the ca. $1500 \mathrm{~km}$ down-dip length of an
American slab observed in seismic tomography under the Lesser Antilles Trench (Li et al. 2008), and (2) fault displacement estimates of ca. $1100-1500 \mathrm{~km}$ from geological field studies at the northern or southern Caribbean Plate boundaries (e.g. Leroy et al. 2000; Escalona and Mann 2011). Total amounts of west - east rifting within the Caribbean Plate (or complementary shortening to the north and south) have not been determined in detail, but so far only minimal amounts have been calculated. For example, Rogers and Mann (2007) documented ca. $85 \mathrm{~km}$ of extension in the western Chortis and Sula rifts, and MandujanoVelazquez and Keppie (2009) calculated ca. $105 \mathrm{~km}$ of shortening in the Chiapas fold-and-thrust belt to the north. Phipps-Morgan et al. (2008) have suggested that further extension may be expressed within the Central American Arc, and James (2009a, b), among others, has suggested that further extension may be expressed between dismembered blocks under the Caribbean Sea east of the Chortis Block.

\section{THE PIRATE MODEL OF CARIBBEAN TECTONICS}

A detailed presentation of the new Pirate model of Caribbean tectonics and a defence of its main points is available elsewhere (Keppie 2012). Here, I take the opportunity to identify two of the conceptual elements of the model and to show why their further consideration in the Caribbean case is appropriate (Fig. 4). These conceptual elements help illustrate two ways in which the western Caribbean corners could have been mostly fixed to North and South American reference frames, while permitting large displacements at the northern, eastern, and southern Caribbean plate boundaries; no extension needs to have taken place within the Caribbean Plate region itself.

First, the capture of microplates from southern North America and northern South America may have occurred across a zone of lateral intrusion (Fig. 4A). In this scenario, widening of the Caribbean Plate could have been accommodated by the rotational capture of microplates into the trailing edge of the Caribbean Plate (Jones et al. 1997; Audemard 2009; 
A In-situ model - fixed variant
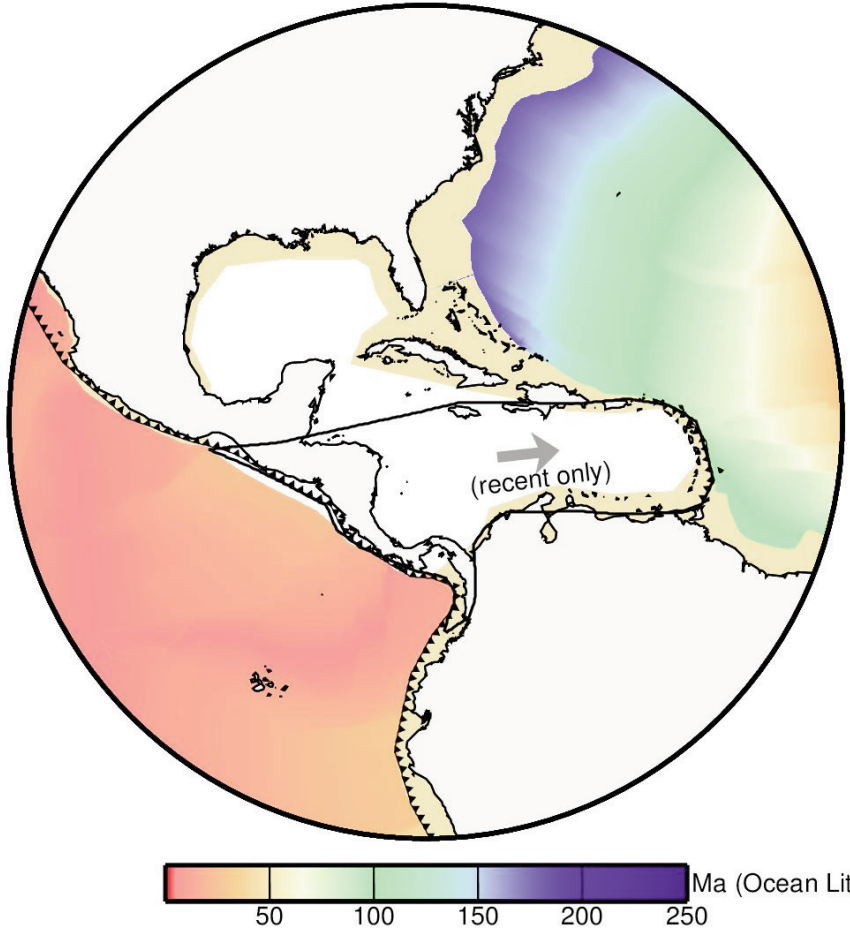

B In-situ model - widening variant

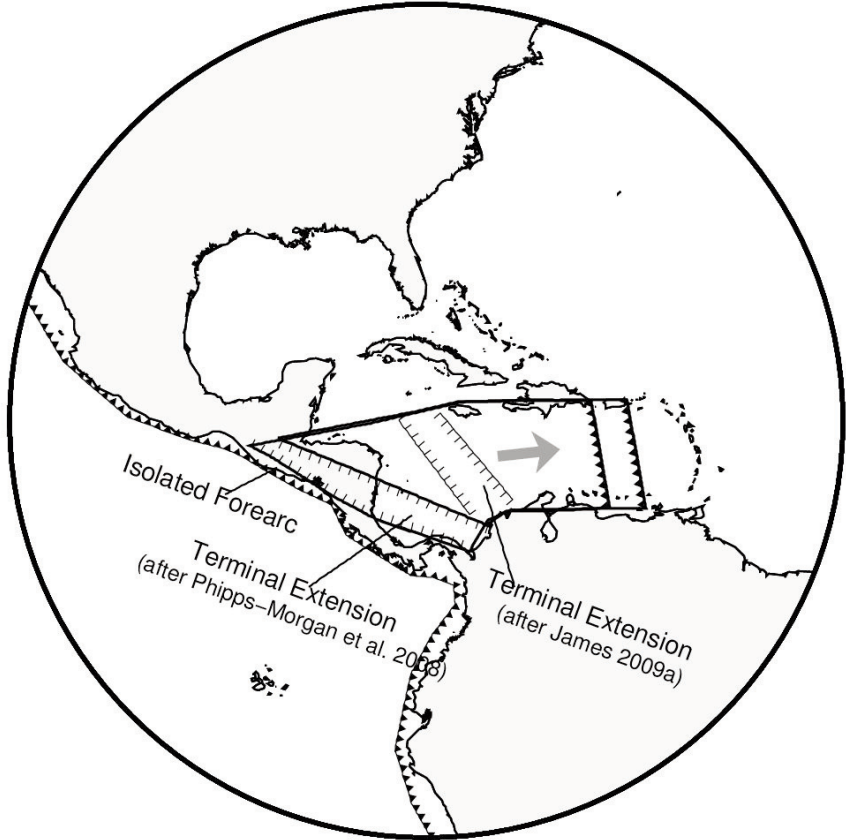

a (Ocean Lithosphere Age)

Figure 3. (A) In situ model with the whole Caribbean Plate fixed to North and South American reference frames (after James 2009a). (B) In situ model with rifting in the western Caribbean region (after Phipps Morgan et al. 2008) or central Caribbean region (after James 2009a).

\section{A Pirate model - microplate variant}

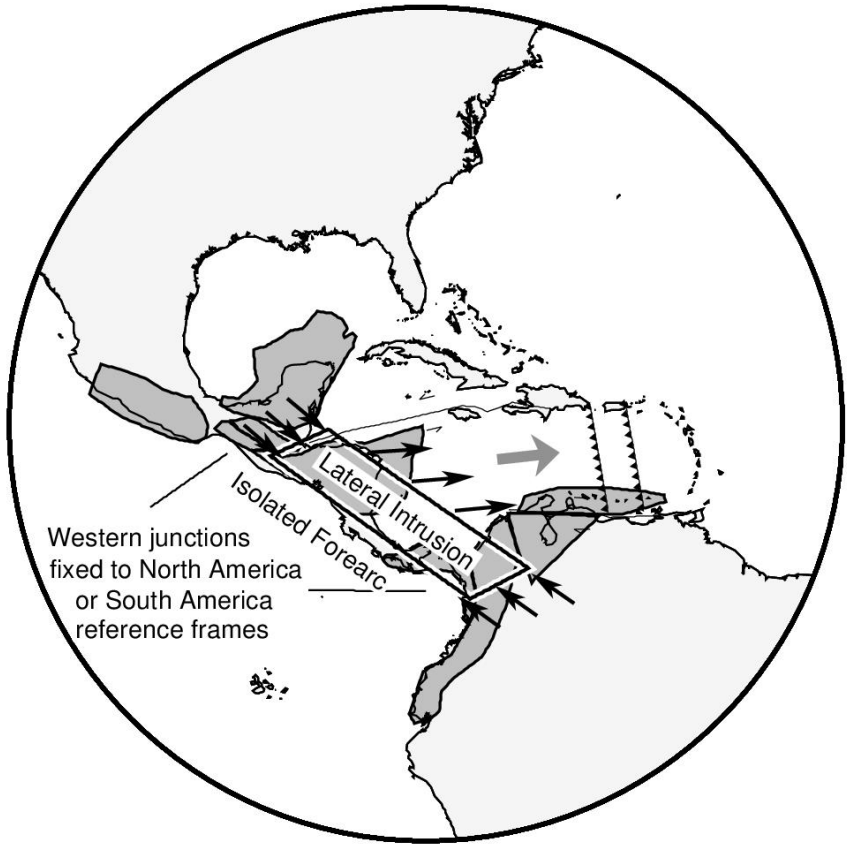

B Pirate model - major plate variant

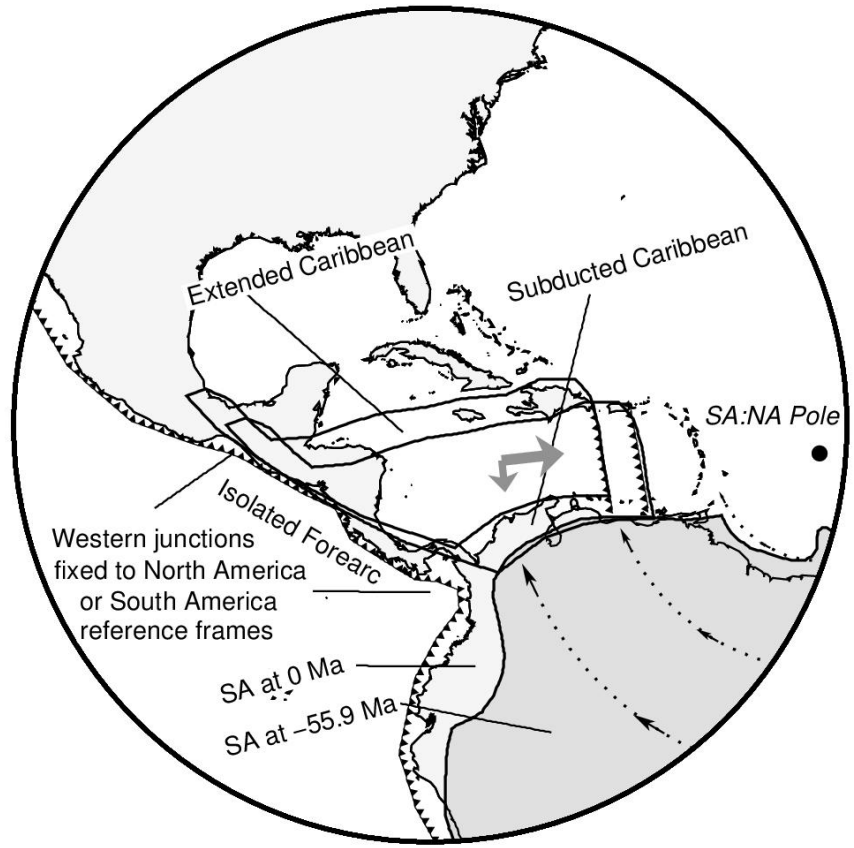

Figure 4. (A) Pirate model with microplate capture across the western Caribbean Plate corners (after Keppie 2012). (B) Pirate model with counter-clockwise rotation of the Caribbean Plate relative to North and South America (after Keppie 2012). 
Authemayou et al. 2011). This requires the northern and southern Caribbean Plate boundaries to curve to the northwest and southwest, respectively, prior to reaching the Middle American Trench, which accords with geological mapping (e.g. Rogers et al. 2007, Authemayou et al. 2011). A consequence of such lateral intrusion is that extension within southern North America and northern South America would ultimately accommodate and balance net displacements across the northern and southern Caribbean Plate boundaries. This could have implications for the evolution of hydrocarbon-bearing basins in western Gulf of Mexico and Venezuela, respectively (Fig. 4A). Andreani et al. (2008), Audemard (2009) and Authemayou et al. (2011) have demonstrated that such kinematics may have governed the recent evolution of the western Caribbean (i.e. since ca. $10 \mathrm{Ma}$ ). The Pirate model is based on the hypothesis that similar kinematics have applied throughout the Late Cretaceous and Cenozoic (Keppie 2012).

The second possibility involves moving the Caribbean Plate to the east-southeast relative to both North and South America (Fig. 4B). In a North American reference frame, counter-clockwise rotation of the whole Caribbean Plate in concert with clockwise rotation of the South American Plate would achieve the required motion. This is consistent with Pindell and Kennan (2009), among others, who deduced east-southeasterly relative motion for the entire Caribbean Plate during the middle Cenozoic, and Müller et al. (1999), among others, who deduced clockwise relative rotation of the South American Plate since ca. 55.9 Ma. Such plate rotations imply stabilization of the western Caribbean corners through transtension at the northern Caribbean Plate boundary and transpression at the southern Caribbean Plate boundary. Both of these kinematic possibilities are invoked in the Pirate model of Caribbean tectonics (Keppie 2012). The Pirate model is distinct from both the Pacific and in situ models for both the origin of the Chortis Block and the evolution of the Gulf of Mexico (e.g. Pindell and Kennan 2009; James 2009a; Stern and Dickinson
2010). In the Pirate model, the Chiapas and Chortis blocks are derived from the western and southwestern parts of the Gulf of Mexico, respectively (Keppie 2012). One of the central potential obstacles for adoption of the Pirate model is then the implied interpretation of active tectonics within the Gulf of Mexico region during Late Cretaceous and Cenozoic time. This is because many authors have hypothesized that the Gulf of Mexico opened entirely prior to the Late Jurassic or Early Cretaceous. New evidence suggests that this timing needs to be reexamined, however. Evidence potentially supporting the interpretation of younger tectonic activity in the Gulf of Mexico(Keppie 2012) includes: (1) Late Cretaceous and Cenozoic thinning of the lower crust beneath the Corsair rift zone (Fig. 1B) in the northwestern Gulf of Mexico (Rangin et al. 2008); (2) Cenozoic intrusion of the Eastern Alkaline Province (Fig. 1B) along the western Gulf of Mexico margin (Cantagrel and Robin 1979); (3) the presence of ca. $2.5 \mathrm{~km}$ of anomalous Cenozoic subsidence preserved in the western Gulf of Mexico basins (Feng et al. 1994); and (4) Cenozoic dextral transpression preserved along the Sierra Madre Oriental of eastern Mexico (English and Johnston 2004). Lastly, the counter-clockwise opening of the Gulf of Mexico itself is poorly understood if it is only Jurassic in age (Dickinson 2009; Stern and Dickinson 2010). Were a component of this opening found to be Late Cretaceous or Cenozoic, its counter-clockwise kinematics would correspond directly to that predicted in the Pirate model.

\section{CONCLUSIONS}

The Mesozoic and Cenozoic tectonic evolution of the Gulf of Mexico and Caribbean regions is complex and key aspects of standard reconstructions are difficult to reconcile with known tectonic mechanisms. For example, how the Gulf of Mexico opened in a counter-clockwise fashion, as is commonly inferred, remains uncertain. Likewise, the inference that differences in upper plate forces controlled slower relative rollback of the Middle America Trench west of Central America, and thus allowed the North and South American Plates to move relatively west past the Chortis Block and the Caribbean Plateau, contrasts with modern theories of slab rollback mechanisms. New geodynamic processes must be identified therefore before the hypothesis of a Pacific origin for the Chortis and Caribbean microplates can be confirmed. As a consequence of these uncertainties, alternative models for the interpretation of the geological record and the tectonic evolution of the Gulf of Mexico and Caribbean regions need to be considered and tested as well.

\section{ACKNOWLEDGEMENTS}

Brendan Murphy is acknowledged for fostering collegial debate and managing the publication of this manuscript and the companion paper by Keith James in a debate format. Rob Raeside and Reg Wilson - who reviewed and edited the manuscripts, as well as Keith James and J. Duncan Keppie are acknowledged for recommending useful changes to the text and figures. Michael Gurnis and Rob Clayton are acknowledged for supporting my study of Caribbean tectonics during my post-doctoral studies.

\section{REFERENCES}

Andreani, L., Le Pichon, X., Rangin, C., and Martínez-Reyes, J., 2008, The southern Mexico block: main boundaries and new estimation for its Quaternary motion: Bulletin de la Société Géologique de France, v. 179, p. 209-223, http:/ /dx.doi.org/ 10.2113/gssgfbull.179.2.209.

Audemard, F.A., 2009, Key issues on the post-Mesozoic Southern Caribbean Plate boundary: Geological Society, London, Special Publications, v. 328, p. 569-586, http://dx.doi.org/10.1144/SP328.23.

Authemayou, C., Brocard, G., Teyssier, C., Simon-Labric, T., Guttiérrez, A., Chiquín, E.N., and Morán, S., 2011, The Caribbean-North AmericaCocos Triple Junction and the dynamics of the Polochic-Motagua fault systems: Pull-up and zipper models: Tectonics, v. 30, TC3010 23 pages, http://dx.doi.org/10.1029/2010TC00 2814.

Cantagrel, J.-M., and Robin, C., 1979, K-Ar dating on eastern Mexican volcanic rocks - Relations between the andesitic and the alkaline provinces: Journal of Volcanology and Geothermal Research, v. 5, p. 99-114, 
http://dx.doi.org/10.1016/03770273(79)90035-0.

DeMets, C., Gordon, R.G., and Argus, D.F., 2010, Geologically current plate motions: Geophysical Journal International, v. 181, p. 1-80, http://dx.doi.org/10.1111/j.1365246X.2009.04491.x.

Dickinson, W.R., 2009, The Gulf of Mexi$\mathrm{co}$ and the southern margin of Laurentia: Geology, v. 37, p. $479-480$, http://dx.doi.org/10.1130/focus0520 09.1.

English, J.M., and Johnston, S.T., 2004, The Laramide Orogeny: What were the driving forces?: International Geology Review, v. 46, p. 833-838, http:/ /dx.doi.org/10.2747/00206814.46.9.833.

Escalona, A., and Mann, P., 2011, Tectonics, basin subsidence mechanisms, and paleogeography of the CaribbeanSouth American plate boundary zone: Marine and Petroleum Geology, v. 28, p. 8-39, http:/ /dx.doi.org/10.1016/j.marpetgeo.2010.01.016.

Feng, Jianhua, Buffler, R.T., and Kominz, M.A., 1994, Laramide orogenic influence on late Mesozoic-Cenozoic subsidence history, western deep Gulf of Mexico basin: Geology, v. 22, p. 359-362,

http://dx.doi.org/10.1130/00917613(1994)022<0359:LOIOLM > 2.3.C $\mathrm{O} ; 2$.

Funk, J., Mann, P., McIntosh, K., and Stephens, J., 2009, Cenozoic tectonics of the Nicaraguan depression, Nicaragua, and Median Trough, El Salvador, based on seismic-reflection profiling and remote-sensing data: Geological Society of America Bulletin, v. 121, p. 1491-1521, http://dx.doi.org/10.1130/B26428.1.

Gurnis, M., Turner, M., Zahirovic, S., DiCaprio, L., Spasojevic, S., Müller, R.D., Boyden, J., Seton, M., Manea, V.C., and Bower, D.J., 2012, Plate tectonic reconstructions with continuously closing plates: Computers and Geosciences, v. 38, p. 35-42, http://dx.doi.org/10.1016/j.cageo.201 1.04.014.

Guzmán-Speziale, M., 2009, A seismotectonic model for the Chortís Block: Geological Society, London, Special Publications, v. 328, p. 197-204, http://dx.doi.org/10.1144/SP328.9.

Guzmán-Speziale, M., 2010, Beyond the Motagua and Polochic faults: Active strike-slip faulting along the Western North America-Caribbean plate boundary zone: Tectonophysics, v. 496, p. 17-27, http://dx.doi.org/10.1016/j.tecto.201 0.10 .002 .

James, K.H., 2009a, Evolution of Middle America and the in situ Caribbean Plate model: Geological Society, London, Special Publications, v. 328, p. 127-138, http://dx.doi.org/10.1144/SP328.4.

James, K.H., 2009b, In situ origin of the Caribbean: discussion of data: Geological Society, London, Special Publications, v. 328, p. 77-125, http://dx.doi.org/10.1144/SP328.3.

Jones, R.R., Holdsworth, R.E., and Bailey, W., 1997, Lateral extrusion in transpression zones: the importance of boundary conditions: Journal of Structural Geology, v. 19, p. 1201-1217, http://dx.doi.org/10.1016/S01918141(97)00034-5.

Keppie, D.F., 2012, Derivation of the Chortis and Chiapas blocks from the western Gulf of Mexico in the latest Cretaceous-Cenozoic: the Pirate model: International Geology Review, p. $1765-1775$, http://dx.doi.org/10.1080/00206814. 2012.676356.

Keppie, D.F., Hynes, A.J., Lee, J.K.W., and Norman, M., 2012, OligoceneMiocene back-thrusting in southern Mexico linked to the rapid subduction erosion of a large forearc block: Tectonics, v. 31, TC2008, http://dx.doi.org/10.1029/2011TC00 2976.

Keppie, D.F., and Keppie, J.D., 2012, An alternative Pangea reconstruction for Middle America with the Chortis Block in the Gulf of Mexico: tectonic implications: International Geology Review, v. 54, p. 1685-1696, http://dx.doi.org/10.1080/00206814. 2012.676361.

Keppie, J.D., and Morán-Zenteno, D.J., 2005, Tectonic Implications of Alternative Cenozoic Reconstructions for Southern Mexico and the Chortis Block: International Geology Review, v. 47, p. 473-491, http://dx.doi.org/10.2747/00206814.47.5.473.

Keppie, J.D., Morán-Zenteno, D.J., Martiny, B., and González-Torres, E., 2009, Synchronous 29-19 Ma arc hiatus, exhumation and subduction of forearc in southwestern Mexico: Geological Society, London, Special Publications, v. 328, p. 169-179, http://dx.doi.org/10.1144/SP328.7.

Lallemand, S., Heuret, A., and Boutelier, D., 2005, On the relationships between slab dip, back-arc stress, upper plate absolute motion, and crustal nature in subduction zones: Geochemistry, Geophysics, Geosystems, v. 6, Q09006 18 pages, http://dx.doi.org/10.1029/2005GC00 0917.

Leroy, S., Mauffret, A., Patriat, P., and Mercier de Lépinay, B., 2000, An alternative interpretation of the Cayman trough evolution from a reidentification of magnetic anomalies: Geophysical Journal International, v. 141, p. 539-557, http://dx.doi.org/10.1046/j.1365246x.2000.00059.x.

Li, Chan, van der Hilst, R.D., Engdahl, E.R., and Burdick, S., 2008, A new global model for $P$ wave speed variations in Earth's mantle: Geochemistry, Geophysics, Geosystems, v. 9, Q05018 21 pages, http://dx.doi.org/10.1029/2007GC00 1806.

Lonsdale, P., 2005, Creation of the Cocos and Nazca plates by fission of the Farallon plate: Tectonophysics, v. 404, p. 237-264,

http://dx.doi.org/10.1016/j.tecto.200 5.05.011.

Mandujano-Velazquez, J.J., and Keppie, J.D., 2009, Middle Miocene Chiapas fold and thrust belt of Mexico: a result of collision of the Tehuantepec Transform/Ridge with the Middle America Trench: Geological Society, London, Special Publications, v. 327, p. 55-69, http://dx.doi.org/10.1144/SP327.4.

Morán-Zenteno, D.J., Keppie, J.D., Martiny, B., and González-Torres, E., 2009, Reassessment of the Paleogene position of the Chortis block relative to southern Mexico: hierarchical ranking of data and features: Revista mexicana de ciencias geológicas, v. 26, p. 177-188.

Müller, R.D., Royer, J.-Y., Cande, S.C., Roest, W.R., and Maschenkov, S., 1999, New constraints on the late Cretaceous/Tertiary plate tectonic evolution of the Caribbean, in Mann, P. ed., Caribbean Basins, Elsevier, p. 33-59.

Müller, R.D., Sdrolias, M., Gaina, C., and Roest, W.R., 2008, Age, spreading rates, and spreading asymmetry of the world's ocean crust: Geochemistry, Geophysics, Geosystems, v. 9, Q04006 19 pages. http://dx.doi.org/10.1029/2007GC00 1743.

Ortega-Gutiérrez, F., Solari, L.A., OrtegaObregón, C., Elías-Herrera, M., Martens, U., Morán-Icál, S., Chiquín, M., Keppie, J.D., De León, R.T., and Schaaf, P., 2007, The Maya-Chortís Boundary: A tectonostratigraphic 
approach: International Geology

Review, v. 49, p. 996-1024, http://dx.doi.org/10.2747/00206814.49.11.996.

Phipps Morgan, J., Ranero, C.R., and Vannucchi, P., 2008, Intra-arc extension in Central America: Links between plate motions, tectonics, volcanism, and geochemistry: Earth and Planetary Science Letters, v. 272, p. 365-371, http://dx.doi.org/10.1016/j.epsl.2008. 05.004 .

Pindell, J., and Dewey, J.F., 1982, PermoTriassic reconstruction of western Pangea and the evolution of the Gulf of Mexico and Caribbean region: Tectonics, v. 1, p. 179-211, http://dx.doi.org/10.1029/TC001i002 p00179.

Pindell, J., and Kennan, L., 2009, Tectonic evolution of the Gulf of Mexico, Caribbean and northern South America in the mantle reference frame: an update: Geological Society, London, Special Publications, v. 328, p. 1-55, http://dx.doi.org/10.1144/SP328.1.

Pindell, J., Kennan, L., Stanek, K.P., Maresch, W.V., and Draper, G., 2006, Foundations of Gulf of Mexico and Caribbean evolution: eight controversies resolved: Geologica Acta, v. 4, p. 303-341.

Rangin, C., Le Pichon, X., Flotté, N., and Husson, L., 2008, Cenozoic gravity tectonics in the northern Gulf of Mexico induced by crustal extension. A new interpretation of multichannel seismic data: Bulletin de la Société Géologique de France, v. 179, p. 117-128, http://dx.doi.org/10.2113/gssgfbull.179.2.117.

Rogers, R.D., and Mann, P., 2007, Transtensional deformation of the western Caribbean-North America plate boundary zone, in Mann, P., ed., Geologic and tectonic development of the Caribbean plate boundary in north central America: Geological Society of America Special Papers, 428, p. 37-64, http://dx.doi.org/10.1130/2007.2428( 03).

Rogers, R.D., Mann, P., and Emmet, P.A., 2007, Tectonic terranes of the Chortis block based on integration of regional aeromagnetic and geologic data, in Mann, P., ed., Geologic and tectonic development of the Caribbean plate boundary in north central America: Geological Society of America Special Papers, 428, p. 65-88, http://dx.doi.org/10.1130/2007.2428( 04).

Ross, M.I., and Scotese, C.R., 1988, A hierarchical tectonic model of the Gulf of
Mexico and Caribbean region:

Tectonophysics, v. 155, p. 139-168, http://dx.doi.org/10.1016/00401951(88)90263-6.

Sandwell, D.T., and Smith, W.H.F., 2009, Global marine gravity from retracked Geosat and ERS-1 altimetry: Ridge segmentation versus spreading rate: Journal of Geophysical Research, v. 114, B01411, 18 pages, http://dx.doi.org/200910.1029/2008J B006008.

Schellart, W.P., Freeman, J., Stegman, D.R., Moresi, L., and May, D., 2007, Evolution and diversity of subduction zones controlled by slab width: Nature, v. 446, p. 308-311, http://dx.doi.org/10.1038/nature0561 5.

Seton, M., Müller, R.D., Zahirovic, S., Gaina, C., Torsvik, T., Shephard, G., Talsma, A., Gurnis, M., Turner, M., Maus, S., and Chandler, M., 2012, Global continental and ocean basin reconstructions since $200 \mathrm{Ma}$ : EarthScience Reviews, v. 113, p. 212-270, http://dx.doi.org/10.1016/j.earscirev. 2012.03.002.

Stegman, D.R., Schellart, W.P., and Freeman, J., 2010, Competing influences of plate width and far-field boundary conditions on trench migration and morphology of subducted slabs in the upper mantle: Tectonophysics, v. 483, p. $46-57$, http://dx.doi.org/10.1016/j.tecto.200 9.08.026.

Stern, R.J., and Dickinson, W.R., 2010, The Gulf of Mexico is a Jurassic backarc basin: Geosphere, v. 6, p. 739 -754, http://dx.doi.org/10.1130/GES00585 .1.

Wilson, J.T., 1966, Are the structures of the Caribbean and Scotia arc regions analogous to ice rafting?: Earth and Planetary Science Letters, v. 1, p. 335-338, http://dx.doi.org/10.1016/0012821X(66)90019-7.

Received February 2012 Accepted as revised January 2013 